\title{
Effects of Local Application of Platelet Rich Fibrin versus Hyaluronic Acid on Postoperative Sequelae After Surgical Removal of Impacted Lower Third Molar
}

\author{
Imad Marouf ${ }^{1}$ and Atalla Rejab ${ }^{2, *}$ \\ ${ }^{1}$ Ministry of health, Erbil, Iraq \\ ${ }^{2}$ Assistant Professor, Dentistry College, University of Mosul, Mosul, Iraq \\ *Corresponding author. Email: atahadeedi@uomosul.edu.iq
}

\begin{abstract}
Objectives: This study aims to evaluate the effectiveness of local application of platelet rich fibrin and hyaluronic acid on postoperative sequelae after surgical extraction of impacted mandibular third molars. Materials and Methods: The research included a total of 66 healthy patients, from both genders, aged between 19-29 years partially erupted mandibular third molar. All procedures had been done under local anesthesia. Patients randomly divided into three groups. First group platelet rich fibrin and in the second group (Gengigel $®$ Prof Syringes, Ricerfarma) which contain $0.8 \%$ hyaluronic acid were applied in the post extraction socket of impacted lower third molar. In the third control group nothing was placed in the extraction sockets. Postoperative pain, swelling, and trismus were evaluated on the 1st, 3rd, and 7th postoperative days. Results: Hyaluronic acid $0.8 \%$ (Gengigel) showed significant reduction in both pain and swelling for the 1st and 3rd postoperative days when compared to the control group. Platelet rich fibrin group revealed a significant lower pain at 1st postoperative day and less swelling at 3rd postoperative day in comparison to the control group. No differences were determined among all groups in maximum mouth opening (trismus). Conclusions: The result of this study showed that both hyaluronic acid and platelet rich fibrin reduced the postoperative pain and swelling. However, the outcome of hyaluronic acid was more satisfied than the platelet rich fibrin in comparison to that of control group after wisdom teeth surgery.
\end{abstract}

Keywords: Third molar, platelet rich fibrin, hyaluronic acid, swelling.

\section{INTRODUCTION}

Impaction of third molar is a prevalent state associated with different degrees of complications that affects postoperative wellness of patients in the first few days following surgical removal [1]. The major complications that occur after surgical extraction of mandibular third molars are delayed wound healing, inflammation, facial swelling, pain, and trismus [2]. Several studies were based on reducing the complications after third molar surgery [3, 4]. Some of these studies concentrated on use of drugs. For example, studies have shown a beneficial outcome from the use of corticosteroids and nonsteroidal anti-inflammatory drugs in minimizing edema and trismus [4, 5]. Nevertheless, these medications may result in significant systemic side effects and are contraindicated in some patients due to their potential side effects such as adrenal suppression, delayed wound healing and increased susceptibility to infection $[6,7]$. These issues encouraged researchers to investigate or research the use of other biomaterials such as Hyaluronic acid [HA] and Platelet rich fibrin [PRF].

Hyaluronic acid or hyaluronan is a high molecular weight glycosaminoglygan (50-8000 kilodalton). Its chemical structure consists of repeated non-sulfated disaccharide units of $\mathrm{N}$ - acetylglucosamine and $\mathrm{D}$ glucuronic acid [8,9]. It is one of components of extracellular matrix of connective tissue, synovial fluid, 
embryonic mesenchyme, vitreous humor, skin, and mineralized hard tissues such as alveolar bone and cementum. It stimulates expression of growth factors by binding to their receptors thus accelerating healing process [10]. It plays a key role in the procedure of morphogenesis and cure of wounds [11, 12]. Hyaluronic acid enhances cell emigration and adhesion and also stimulates cell proliferation and specialization [13-16].

Platelet rich fibrin [PRF] clots, were developed by Choukroun et al. [17]. Platelet rich fibrin consists of a polymerized fibrin matrix in a trimolecular system containing platelets, leukocyte, cytokines, and circulating stem cells [18]. Such a complex makes PRF a curative biomaterial that favors soft tissue and bone regeneration [19]. Several studies have shown that PRF has facilitated the healing of wounds such as following the removal of cysts, sinus augmentations and periodontal defects [17, 20, 21].

\section{MATERIALS AND METHODS}

\subsection{PATIENT SELECTION}

The study is a randomized, blinded, prospective study conducted at the Dental Collective Hospital in Erbil, Iraq. Sixty-six patients aged between 19-29 years old were enrolled in this study following an informed verbal and written consent. The patients had either [vertical, mesioangular, disto-angular, or horizontal] type of impaction according to Winter's classification of impaction and class II level B according to Bell and Gregory classification of impaction with partial or total bone cover.

\subsubsection{Inclusion Criteria}

1. Patients that fulfilled the research demands including follow-up sessions and informed signing of consent.

2. Patients with no systemic diseases.

3. Patient with no history of bleeding problems.

4. Patients free from allergies.

\subsubsection{Exclusion Criteria}

1. Patients on chronic medications such as steroidal and non-steroidal anti-inflammatory drugs, antihistamines, and other drugs that may affect evaluation of postoperative responses.

2. Presence of acute infection such as pericoronitis and / or pain on the tooth site.

3. Pregnant and lactating women.

4. Patients that fulfilled the demands, but at surgery the procedure take time more than one hour.

\subsection{Study Design}

In order to minimize differences, patients were operated by the same oral surgeon with a standardized surgical technique and equipments. Patients were divided randomly into three groups: Hyaluronic acid group ([22 patients), Platelet rich fibrin group (22 patients), and Control group (22 patients).

\subsection{Preparation of Standardized PRF}

Prior to giving anesthesia, 2 tubes of ten $\mathrm{ml}$ venous blood were collected from each patient in glass coated plastic tubes (AYSET,turkey) and immediately centrifuged (800 electric centrifuge, china) at $3000 \mathrm{rpm}$ for $10 \mathrm{~min}$. according to Choukroun's method. At completion of centrifugation cycle, the tubes were collected and caps of tubes removed. The blood sample separates into three visible layers: an acellular plasma at the top of the tube; a polymerized fibrin clot in the middle; and blood cells (red corpuscle base) are gathered at the bottom of the test tube, as shown in Figure 1. The tubes were placed in a tube rack, allowing the formed clot to mature for approximately 4-8 minutes [22]. The middle layer (PRF clot) is removed using sterile tweezers and separated by scissors from the underlying red corpuscular base.

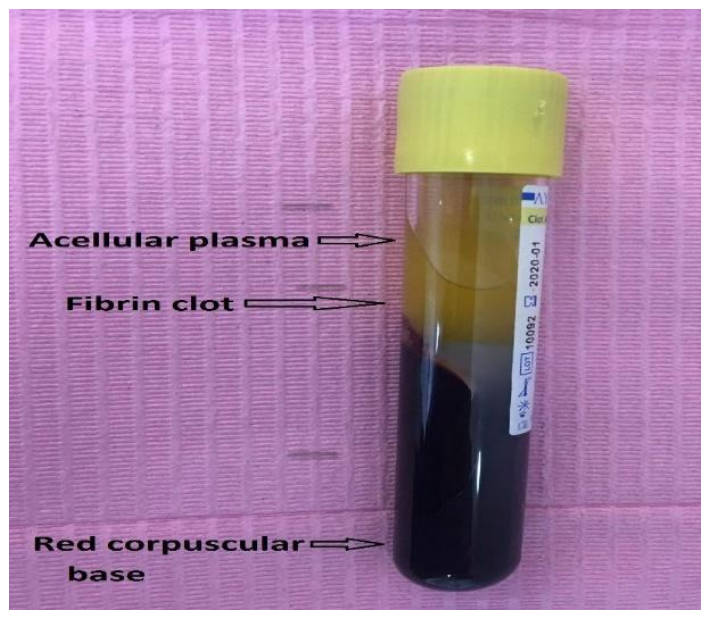

Figure 1 Glass coated plastic tube with three layers: Top layer (acellular plasma); Middle layer (PRF clot); Basal layer (red corpuscular base).

\subsection{Application of [Gengigel $®$ Prof Syringes, Ricerfarma] for the Hyaluronic Acid Group:}

The $1 \mathrm{ml}$ of prefilled syringe was used together with a disposable tip specifically designed with a long and flexible plastic needle to guarantee the best application of Gengigel deep into the extraction socket which contains 
$0.8 \%$ of hyaluronic acid in addition to (aqua, xylitol, and other excipients). The screw cap from the syringe is removed then disposable tip was fitted for use on the patient extracted impacted third molar socket. As shown in Figure 2. Each syringe is used one time and for one .patient

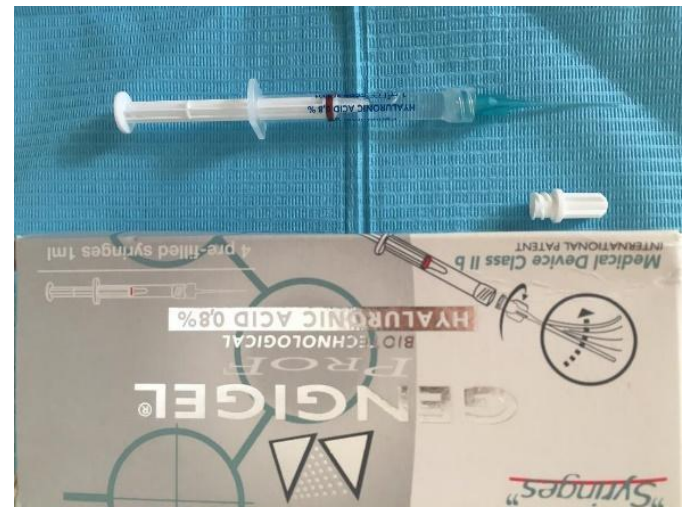

Figure 2 Preparation of Hyaluronic acid gel

\subsection{Surgical Procedure}

Routine regional anesthesia was applied including inferior alveolar and lingual nerve blocks together with buccal infiltration anesthesia. Two cartilages of lidocaine hydrochloride $2 \%$ solution with 1:80.000 epinephrine (septodent, France) were used. After incision, a mucoperiosteal soft tissue flap was reflected laterally and bone osteotomy with straight surgical handpiece and bur coupled with copious saline irrigation was done. Sometimes according to type of tooth angulation as in horizontal type, sectioning and separation of tooth crown was done. Following tooth extraction, sharp edges were smoothed with bone file, the socket irrigated and debrided mechanically. In platelet rich fibrin group clot was removed with sterile tweezers and separated from the underlying red corpuscular base by using scissors and then transferred to the extraction socket, as shown in Figure 3. In hyaluronic acid group, $1 \mathrm{~mL}$ Gengigel Prof pre-filled Syringe $(0.8 \%$ HA) was applied in postextraction sockets as shown in figure 4 . Nothing was applied in the postextraction bony socket in the control group. The flap was sutured with silk 3/0. Gauze pressure packs were applied to the operation site to aid in hemostasis. All patients were instructed to eat soft and cold diet for the first 24 hours after operation and instructed not to gargle for the first postoperative day. Postoperative medications consisted of amoxicillin $1 \mathrm{gm}$ (SDI, IRAQ) twice per day for 5 days with paracetamol tablet (AWAMEDICA, Erbil) 500 mg every eight hours for 2 days after operation.

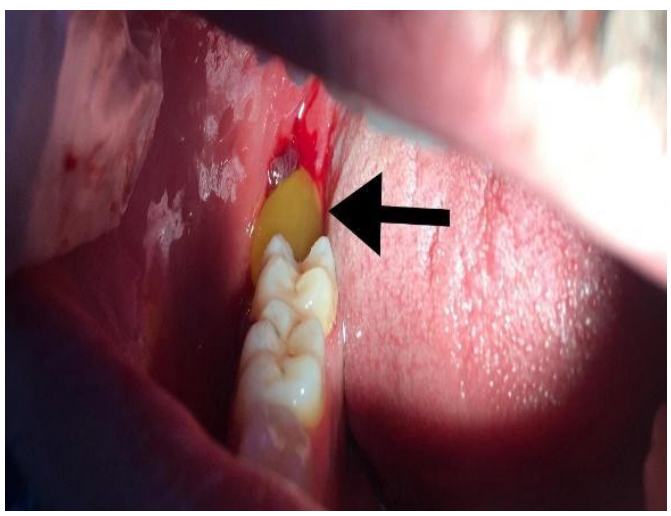

Figure 3 Placing of PRF in the Socket

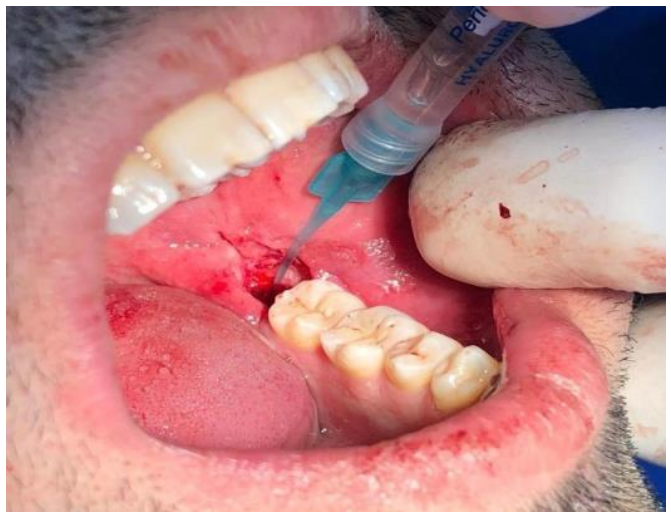

Figure 4 Applicationof hyaluronic acid in the Socket

\subsection{Postoperative Evaluation}

All patients were recalled on the postoperative 1st, 3rd, and 7th days after surgical extraction of impacted mandibular third molar to evaluate pain, facial swelling, and trismus.

Postoperative assessment of facial swelling was taken with a modification of the tape measure method described by Gabka and Matsumara [23] before surgery as a base line and at $1 \mathrm{st}, 3 \mathrm{rd}$, and 7 th postoperative days. Linear measurements were made from anatomical angle of mandible to tragus $(\mathrm{T})$, lateral canthous of eye $(\mathrm{CE})$, lateral border of ala of nose (AN), corner of mouth (CM), soft tissue pogonion (P). As shown in figure 5. Five different measurements were recorded [24]. 


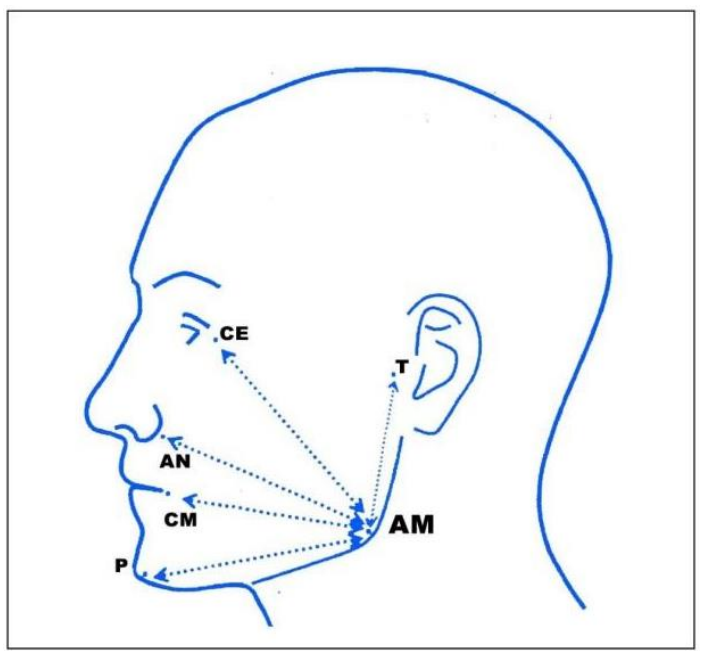

Figure 5 Reference points for measurement of swelling

Measuring postoperative pain was recorded using a numerical pain rating scale (NPS) [25], which has 10 units number line marked by degrees. Score of 0 indicates "absence of pain" and score of 10 indicates "excessive pain" while intermediate scores indicates "moderate pain". The patients were educated about the meaning of scores at the beginning and were asked to express their intensity of pain by placing a mark on the scale.

Pre and postoperative degree of mouth opening were used to determine the degree of trismus. Maximal interincisal mouth opening was measured using an electronic digital caliper (electronic Vernier, china) as shown in figure 6 .

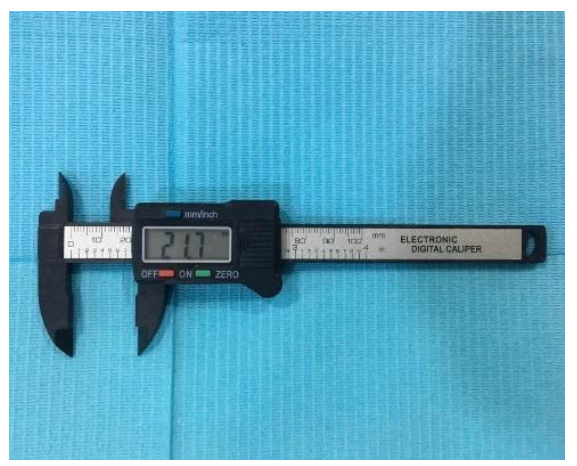

Figure 6 Digital electronic vernier

\section{RESULTS}

The study included a total of 66 patients aged 19-29 years [mean age $=24.2]$. Twenty-four patients were male (34\%), and 42 patients were female (66\%). Pain values measured with the NPS, whilst facial swelling was calculated as each postoperative measurement minus preoperative reading then taking the average of the five measurements for each patient over the days of review. The mean difference of trismus was calculated for each patient as preoperative measurement of opening the mouth minus postoperative reading at each postoperative day then taking the average of the measurements at each

\begin{tabular}{|c|c|c|c|c|c|}
\hline \multirow{2}{*}{\multicolumn{2}{|c|}{ Groups }} & \multicolumn{3}{|c|}{ Postoperative swelling score } & \multirow{2}{*}{$\begin{array}{l}\text { Repeated } \\
\text { Measures } \\
\text { Test }\end{array}$} \\
\hline & & 1st Day & 3rd Day & 7th Day & \\
\hline \multirow{2}{*}{\multicolumn{2}{|c|}{ Control }} & \multirow[t]{2}{*}{$5.85 \pm 1.38$} & \multirow[t]{2}{*}{$3.58 \pm 1.25$} & \multirow{2}{*}{$\begin{array}{l}0.73 \pm 0.6 \\
1\end{array}$} & $\begin{array}{l}\mathrm{F}= \\
170.514\end{array}$ \\
\hline & & & & & $\mathrm{p}=0.000^{*}$ \\
\hline \multirow{2}{*}{\multicolumn{2}{|c|}{ HA }} & \multirow{2}{*}{$4.52 \pm 1.86$} & \multirow{2}{*}{$2.33 \pm 1.06$} & \multirow{2}{*}{$\begin{array}{l}0.50 \pm 0.7 \\
1\end{array}$} & $\begin{array}{l}\mathrm{F}= \\
117.983\end{array}$ \\
\hline & & & & & $\mathrm{p}=0.000^{*}$ \\
\hline \multirow{2}{*}{\multicolumn{2}{|c|}{ PRF }} & \multirow{2}{*}{$4.95 \pm 0.86$} & \multirow{2}{*}{$2.50 \pm 0.74$} & \multirow{2}{*}{$\begin{array}{l}0.65 \pm 1.0 \\
7\end{array}$} & $\begin{array}{l}\mathrm{F}= \\
185.206\end{array}$ \\
\hline & & & & & $\mathrm{p}=0.000 *$ \\
\hline & \multirow{2}{*}{$\begin{array}{l}\text { Contro } \\
1 \text { and } \\
\mathrm{HA}\end{array}$} & $\mathrm{U}=118.0$ & $\mathrm{U}=108.0$ & $\mathrm{U}=171.5$ & \\
\hline & & $\mathrm{p}=0.004 *$ & $\mathrm{p}=0.002^{*}$ & $\mathrm{p}=0.089$ & \\
\hline ב. & \multirow{2}{*}{$\begin{array}{l}\text { Contro } \\
1 \text { and } \\
\text { PRF }\end{array}$} & $\mathrm{U}=146$ & $\mathrm{U}=105.5$ & $\mathrm{U}=178$ & \\
\hline 至 & & $\mathrm{p}=0.061$ & $\mathrm{p}=0.001 *$ & $\mathrm{p}=0.117$ & \\
\hline$D_{2}$ & \multirow{2}{*}{$\begin{array}{l}\text { HA } \\
\text { and } \\
\text { PRF }\end{array}$} & $\mathrm{U}=169.5$ & $\mathrm{U}=219.0$ & $\mathrm{U}=222.5$ & \\
\hline & & $\mathrm{p}=0.088$ & $\mathrm{p}=0.587$ & $\mathrm{p}=0.617$ & \\
\hline
\end{tabular}

postoperative day (1st, 3rd and 7 th) for each study group. SPSS version 20.0 was used for the statistical analysis.

Friedman test $(\mathrm{p}<0.05)$ and repeat measure test ([p $<0.05$ ) showed that pain and swelling decreased significantly in HA, PRF and control groups over the postoperative 1st, 3rd and 7th days. However, KruskalWallis test $(p<0.05)$ revealed that there were statistically significant differences between HA and control group at 1st, 3rd and 7th postoperative days, whilst PRF group showed a significant difference with control group just at 1st day (Table 1).

The results of Mann Whitney test $(\mathrm{p}<0.05)$ revealed that difference in swelling between HA and control group was significant at the 1st and 3rd postoperative days, whilst PRF showed a significant less swelling just at 3rd day (Table 2). However, HA, PRF and control groups showed no significant difference related to trismus (Table $3)$. 
The linear decrease in pain, swelling and trismus over days of review in three study groups are shown in Figure 7.

Table 1 The pain score in Control, Platelet rich fibrin and Hyaluronic acid groups at $1^{\text {st }}, 3^{\text {rd }}$ and $7^{\text {th }}$ post-operative days

\begin{tabular}{|c|c|c|c|c|c|}
\hline \multirow{2}{*}{\multicolumn{2}{|c|}{ Groups }} & \multicolumn{3}{|c|}{ Postoperative pain score } & \multirow{2}{*}{$\begin{array}{l}\text { Friedman } \\
\text { test }\end{array}$} \\
\hline & & 1st Day & 3rd Day & 7th Day & \\
\hline \multirow{2}{*}{\multicolumn{2}{|c|}{ Control }} & \multirow[t]{2}{*}{$\begin{array}{l}6.95 \pm 2 . \\
68\end{array}$} & \multirow[t]{2}{*}{$\begin{array}{l}3.68 \pm 2 . \\
42\end{array}$} & \multirow[t]{2}{*}{$1.68 \pm 2.30$} & $\begin{array}{l}\text { Chi- } \\
\text { Square= } \\
24.072\end{array}$ \\
\hline & & & & & $\mathrm{p}=0.000^{*}$ \\
\hline \multirow{2}{*}{\multicolumn{2}{|c|}{ HA }} & \multirow[t]{2}{*}{$\begin{array}{l}3.14 \pm 1 . \\
83\end{array}$} & \multirow[t]{2}{*}{$\begin{array}{l}1.73 \pm 1 . \\
67\end{array}$} & \multirow[t]{2}{*}{$0.55 \pm 1.26$} & $\begin{array}{l}\text { Chi- } \\
\text { Square= } \\
37.507\end{array}$ \\
\hline & & & & & $\mathrm{p}=0.000 *$ \\
\hline \multirow{2}{*}{\multicolumn{2}{|c|}{ PRF }} & \multirow[t]{2}{*}{$\begin{array}{l}4.41 \pm 2 . \\
09\end{array}$} & \multirow[t]{2}{*}{$\begin{array}{l}2.27 \pm 1 . \\
58\end{array}$} & \multirow[t]{2}{*}{$0.82 \pm 1.18$} & $\begin{array}{l}\text { Chi- } \\
\text { Square= } \\
37.013\end{array}$ \\
\hline & & & & & $\mathrm{p}=0.000^{*}$ \\
\hline \multirow{6}{*}{ 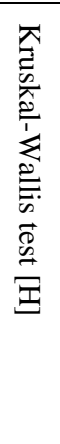 } & \multirow{2}{*}{$\begin{array}{l}\text { Control } \\
\text { and HA }\end{array}$} & $\begin{array}{l}\mathrm{H}= \\
20.852\end{array}$ & $\begin{array}{l}\mathrm{H}= \\
7.552\end{array}$ & $\mathrm{H}=4.074$ & \\
\hline & & $\begin{array}{l}\mathrm{p}= \\
0.000^{*}\end{array}$ & $\begin{array}{l}\mathrm{p}= \\
0.006^{*}\end{array}$ & $\mathrm{p}=0.044^{*}$ & \\
\hline & \multirow{2}{*}{$\begin{array}{l}\text { Control } \\
\text { and PRF }\end{array}$} & $\begin{array}{l}\mathrm{H}= \\
11.973\end{array}$ & $\begin{array}{l}\mathrm{H}= \\
4.087\end{array}$ & $\mathrm{H}=0.301$ & \\
\hline & & $\begin{array}{l}\mathrm{p}= \\
0.001 *\end{array}$ & $\begin{array}{l}\mathrm{p}= \\
0.051\end{array}$ & $\mathrm{p}=0.583$ & \\
\hline & \multirow{2}{*}{$\begin{array}{l}\mathrm{HA} \text { and } \\
\mathrm{PRF}\end{array}$} & $\begin{array}{l}\mathrm{H}= \\
4.128 \\
\end{array}$ & $\begin{array}{l}\mathrm{H}= \\
1.351 \\
\end{array}$ & $\mathrm{H}=2.989$ & \\
\hline & & $\begin{array}{l}\mathrm{p}= \\
0.042\end{array}$ & $\begin{array}{l}\mathrm{p}= \\
0.245\end{array}$ & $\mathrm{p}=0.084$ & \\
\hline
\end{tabular}

Table 2 The swelling for Control, Platelet rich fibrin and Hyaluronic acid groups at $1^{\text {st }}, 3^{\text {rd }}$ and $7^{\text {th }}$ post-operative days

Table 3 Mean difference of postoperative trismus for Control, Platelet rich fibrin and Hyaluronic acid groups at $1^{\text {st }}, 3^{\text {rd }}$ and $7^{\text {th }}$ post-operative days

\begin{tabular}{|c|c|c|c|c|}
\hline \multirow{2}{*}{ Groups } & \multicolumn{3}{|c|}{$\begin{array}{l}\text { Postoperative trismus } \\
\text { score }\end{array}$} & \multirow{2}{*}{$\begin{array}{l}\text { Repeated } \\
\text { Measures } \\
\text { Test }\end{array}$} \\
\hline & $\begin{array}{l}\text { 1st } \\
\text { Day }\end{array}$ & $\begin{array}{l}\text { 3rd } \\
\text { Day }\end{array}$ & 7th Day & \\
\hline \multirow{2}{*}{ Control } & \multirow{2}{*}{$\begin{array}{l}12.55 \\
\pm 7.05\end{array}$} & \multirow{2}{*}{$\begin{array}{l}9.00 \pm \\
6.46\end{array}$} & \multirow{2}{*}{$\begin{array}{l}3.20 \pm 5.2 \\
2\end{array}$} & $F=24.666$ \\
\hline & & & & $\mathrm{p}=0.000^{*}$ \\
\hline \multirow{2}{*}{ HA } & \multirow{2}{*}{$\begin{array}{l}10.19 \\
\pm 5.95\end{array}$} & \multirow{2}{*}{$\begin{array}{l}6.5 \pm 5 \\
69\end{array}$} & \multirow{2}{*}{$\begin{array}{l}1.89 \pm 2.2 \\
3\end{array}$} & $\mathrm{~F}=41.501$ \\
\hline & & & & $\mathrm{p}=0.000^{*}$ \\
\hline \multirow{2}{*}{ PRF } & \multirow{2}{*}{$\begin{array}{l}10.57 \\
\pm 7.61\end{array}$} & \multirow{2}{*}{$\begin{array}{l}7.22 \pm \\
7.30\end{array}$} & \multirow{2}{*}{$\begin{array}{l}2.26 \pm 2.3 \\
9\end{array}$} & $\mathrm{~F}=25.693$ \\
\hline & & & & $\mathrm{p}=0.000^{*}$ \\
\hline
\end{tabular}

\begin{tabular}{|c|c|c|c|c|}
\hline & \multirow{2}{*}{$\begin{array}{l}\text { Contr } \\
\text { ol } \\
\text { and } \\
\text { HA }\end{array}$} & $\begin{array}{l}U= \\
195\end{array}$ & $\begin{array}{l}U= \\
179\end{array}$ & $\begin{array}{l}U= \\
218.5\end{array}$ \\
\hline & & $\begin{array}{l}\mathrm{p}= \\
0.27\end{array}$ & $\begin{array}{l}\mathrm{p}= \\
0.139\end{array}$ & $\mathrm{p}=0.577$ \\
\hline & \multirow{2}{*}{$\begin{array}{l}\text { Contr } \\
\text { ol } \\
\text { and } \\
\text { PRF }\end{array}$} & $\begin{array}{l}U= \\
200.5\end{array}$ & $\begin{array}{l}U= \\
182\end{array}$ & $\begin{array}{l}\mathrm{U}= \\
236.5\end{array}$ \\
\hline & & $\begin{array}{l}\mathrm{p}= \\
0.330\end{array}$ & $\begin{array}{l}\mathrm{p}= \\
0.159\end{array}$ & $p=0.896$ \\
\hline & \multirow{2}{*}{$\begin{array}{l}\text { HA } \\
\text { and } \\
\text { PRF }\end{array}$} & $\begin{array}{l}\mathrm{U}= \\
234.5\end{array}$ & $\begin{array}{l}U= \\
224.0\end{array}$ & $\begin{array}{l}\mathrm{U}= \\
228.0\end{array}$ \\
\hline & & $\begin{array}{l}p= \\
0.860\end{array}$ & $\begin{array}{l}p= \\
0.672\end{array}$ & $\mathrm{p}=0.740$ \\
\hline
\end{tabular}
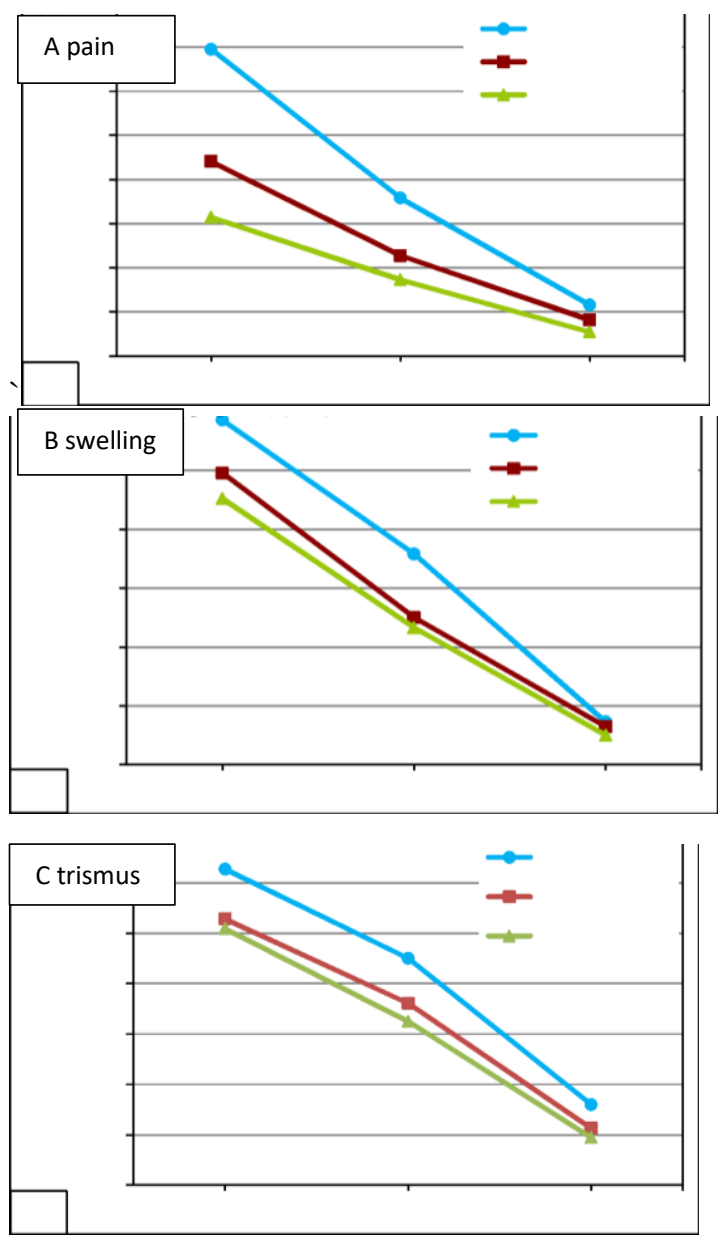

Figure 7 linear decreasing in (a) Pain, (b) swelling and (c) trismus over postoperative days

\section{DISCUSSION}

Impacted third molar removal by surgery causes injury of the soft tissue and bony structures in the oral cavity. Signs and symptoms of edema, pain, and limited opening of the mouth after operation can occur due to muscle spasm [26]. An important event in the field of oral 
surgery department occurred by the use of platelet rich fibrin (PRF) and hyaluronic acid.

The aims of this study is to compare between effects of postoperative application of PRF and hyaluronic acid in reducing pain, swelling, and trismus after the surgical removal of mandibular third molar.

Hyaluronic acid is thought to stimulate cell migration, adhesion, reproduction and differentiation leading to tissue reconstruction, reepithelialization of epidermis, and bone formation [13]. It possesses various physiological and structural functions, which include interactions among cellular and extracellular components, interactions with growth factors and regulation of homeostasis, and tissue lubrication [10]. The therapeutic action of hyaluronic acid depends on the molecular weight with high molecules being antiinflammatory, whereas smaller molecules are proinflammatory [27].

Choukroun described PRF which is naturally prepared without the addition of thrombin [17]. An essential coagulation glycoprotein called thrombospondin-1 and three main growth factors involving vascular endothelial growth factor (VEGF), transforming growth factor $\beta-1$, platelet-derived growth factor (PDGF) are released from PRF for 1 week duration after application [28]. PRF also secrete other types of factors of growth including epidermal growth factor, fibroblast growth factor, and three substantial proinflammatory cytokines; include interleukin (IL)- 1b, IL-6, and tumor necrosis factor alpha (TNF- $\alpha)$. These constituents make PRF a curative biomaterial that enables optimal healing through the fast and effective regeneration of hard and soft tissues [17, 28, 29].

Although numerous studies have previously covered the effects of using HA with control group or PRF with the control group on postoperative sequelae, no studies were found comparing between HA and PRF effects after surgical extraction of mandibular third molar and the simultaneous assessment of both subjective and objective postoperative sequelae.

\subsection{Pain}

Most of the postoperative extraction complications are in fact manifested as pain, it begins after the anesthesia subside and reaches its peak levels during the first postoperative day.

Many studies in the literature reported that HA reduces symptoms of pain for the patients with osteoarthritis. Das et al. [30] suggested that HA has a benefit for patients with osteoarthritis knee pain in reducing symptoms as much as oral nonsteroidal anti- inflammatory drugs or steroid injection. Deleme and Hammed [31] showed that topical Hyaluronic acid gel [Kin ${ }^{\circledR C}$ Care] was as efficient as diclofenac tablets in reducing the pain and swelling after surgical removal of impacted wisdom teeth, they advised to use hyaluronic acid instead of non-steroidal anti-inflammatory drugs for reducing pain for medically compromised patients.

Al- Hamed et al. [32] showed that PRF significantly reduced postoperative pain and analgesic intake following surgical removal of impacted third molars for few postoperative days. However, he recommended that this should be considered with caution because it is based on the subjective visual analogue scale, sensation of pain and response to analgesics, which differ from individual to another.

On the contrary to our study, Yilmaz et al. [33] showed that local administration of HA into the extraction socket may provide a decrease in pain which is not significant. This result may be attributed into several limitations including small sample size pilot study conducted among 25 patients and individual variation in pain threshold.

HA group versus PRF group: The HA group showed better results comparing to PRF group, as the pain in HA group was consistently lower than PRF group, however the result is statistically significant just in the first postoperative day.

\subsection{Swelling}

One of the short-term complications of the third molar surgery is swelling. It is a normal physiologic response of the tissue to surgical trauma that lead to inflammatory response. Swelling usually reaches its maximum at 1-2 days after the surgery. It begins to subside on the third or fourth day and usually ends on the first week [34].

Koray et al. [35] reported that HA spray after third molar extraction reduced facial swelling on the 2nd postoperative day. The surgeon and patients were blinded in their study to the allocation of the HA spray, but the follow up examiner was not. Nelson et al. [36] suggested that oral HA [Oralvisc ${ }^{\circledR}$ ] administration reduces not only pain but also inflammation and he noticed a significant decrease in the majority of inflammatory cytokines that support a chain of reactions leading to inflammation and destruction in the joints of patients with knee osteoarthritis. Cytokines that are decreased in joint fluid and serum include IL- $1 \alpha$, IL-1 $\beta$, IL- 6 , interferon and tumor TNF- $\alpha$. HA is more effective in controlling the postsurgical edema resulting from the inflammatory process by slowing movement of leukocytes by binding to its ligand CD44 [37]. 
Ozgul et al. [38] study results indicated that PRF was more effective in reducing edema in the third day after surgery. Kumar et al. [29] also reported that use of PRF in extraction socket resulted in reduction of edema after 1 st postoperative day.

In reverse to our results, Gokhan et al. [39] reported that HA gel prolonged bleeding time and increased edema in the early postoperative days after extraction of vertical half impacted mandibular third molars. This consequence may be attributed to HA at high concentration inhibits platelet aggregation and adhesion.

HA group versus PRF group: The HA group showed a slightly less mean swelling compared to PRF group in the $1 \mathrm{st}, 3 \mathrm{rd}$, 7th postoperative day, therefore the difference between the two groups is not significant.

\subsection{Trismus}

The trismus in the HA group is less than PRF and control group, also the trismus in the PRF group is less than in the control group. However, the results have not showed any significant difference in the mean trismus among the three groups in the 1st, 3rd and 7th postoperative day respectively.

Afat et al. [40], studied the effects of leukocyte- and platelet-rich fibrin (L-PRF) alone and combined with a hyaluronic acid sponge on swelling and trismus after mandibular third molar surgery and he showed that there was no significant difference among groups in trismus. Bilginaylar et al. [41] also revealed that PRF both in the study and control groups has no significant effects on interincisal mouth opening.

\section{CONCLUSIONS}

- Intra-socket application of HA $0.8 \%$ per $1 \mathrm{ml}$ [Gengigel $®$ Prof Syringes, Ricerfarma Italy] or standardized platelet rich fibrin can be an effective primary way to decrease postoperative pain and swelling after mandibular third molar surgery.

- Prevention and control of postoperative pain and swelling after surgical extraction of impacted mandibular third molar with the use of HA $0.8 \%$ per $1 \mathrm{ml}$ [Gengigel (B) Prof Syringes, Ricerfarma, Italy) is more effective and more superior when compared with the use of standardized platelet rich fibrin.

\section{REFERENCES}

[1] Juodzbalys G, Daugela P. Mandibular third molar impaction: Review of literature and a proposal of a classification. Journal of oral \& maxillofacial research. 2013: 4(2).
[2] Blondeau F, Daniel NG. Extraction of impacted mandibular third molars: postoperative complications and their risk factors. Journal of the Canadian Dental Association. 2007: 73(4).

[3] Xue P, Hou R, Shang L, Ma Y, Wu F, Zhang S. Effect of antibiotics on postoperative inflammatory complications after surgical extraction of the impacted mandibular third molar. Chinese journal of stomatology. 2014: 49(10): 603-606.

[4] Van der Goes MC, Jacobs JW, Bijlsma JW. The value of glucocorticoid co-therapy in different rheumatic diseases-positive and adverse effects. Arthritis research and therapy. 2014: 16(2): 1-13.

[5] Piecuch JF. What strategies are helpful in the operative management of third molars? Journal of oral and maxillofacial surgery. 2012: 70(9): S25S32.

[6] Üstün Y, Erdoğan Ö, Esen E, Karsli ED. Comparison of the effects of 2 doses of methylprednisolone on pain, swelling, and trismus after third molar surgery. Oral Surgery, Oral Medicine, Oral Pathology, Oral Radiology, and Endodontology. 2003: 96(5): 535-539.

[7] Kim K, Brar P, Jakubowski J, Kaltman S, Lopez E. The use of corticosteroids and nonsteroidal antiinflammatory medication for the management of pain and inflammation after third molar surgery: a review of the literature. Oral Surgery, Oral Medicine, Oral Pathology, Oral Radiology, and Endodontology. 2009: 107(5): 630-640.

[8] Moseley R, Leaver M, Walker M, et al. Comparison of the antioxidant properties of HYAFF®-11p75, AQUACEL $®$ and hyaluronan towards reactive oxygen species in vitro. Biomaterials, 2002: 23(10): 2255-2264.

[9] Prince CW. Roles of hyaluronan in bone resorption. Musculoskeletal Disorders 2004: 5(1): 1-3.

[10] Dahiya P, Kamal RJNAjoms. Hyaluronic acid: a boon in periodontal therapy. North American Journal of medical sciences. 2013: 5(5): 309.

[11] Aslan M, Şimşek G, Dayi EJJoba. The effect of hyaluronic acid-supplemented bone graft in bone healing: experimental study in rabbits. Journal of biomaterials applications. 2006: 20(3): 209-220.

[12] Dechert TA, Ducale AE, Ward SI, Yager DR. Hyaluronan in human acute and chronic dermal 
wounds. Wound Repair and Regeneration.2006: 14(3): 252-258

[13] Arosarena OA, Collins WL. Bone regeneration in the rat mandible with bone morphogenetic protein2: a comparison of two carriers. OtolaryngologyHead and Neck Surgery. 2005: 132(4): 592-597.

[14] Grigolo B, Roseti L, Fiorini M, Fini M, Giavaresi G, Aldini NN, and Facchini A. Transplantation of chondrocytes seeded on a hyaluronan derivative (Hyaff®-11] into cartilage defects in rabbits. Biomaterials. 2001: 22(17): 2417-2424.

[15] Lisignoli G, Fini M, Giavaresi G, Aldini NN, Toneguzzi S, Facchini A. Osteogenesis of large segmental radius defects enhanced by basic fibroblast growth factor activated bone marrow stromal cells grown on non-woven hyaluronic acidbased polymer scaffold. Biomaterials. 2002: 23(4): 1043-1051.

[16] Toole BP, Wight TN, Tammi MI. Hyaluronan-cell interactions in cancer and vascular disease. Journal of Biological Chemistry. 2002: 277(7): 4593-4596.

[17] Choukroun J, Adda F, Schoeffler C, Vervelle A. PRF: an opportunity in perio-implantology. Implantodontie. 2001; 42:55-62.

[18] Dohan DM, Choukroun J, Diss A, Dohan SJ, Dohan AJ, Mouhyi J, et al. Platelet-rich fibrin [PRF]: a second-generation platelet concentrate. Part II: platelet related biologic features. Oral Surg Oral Med Oral Pathol Oral Radiol Endod. 2006; 101(3): e45-50.

[19] Choukroun J, Diss A, Simonpieri A, Girard MO, Schoeffler C, Dohan SL, Dohan AJ, Mouhyi J, Dohan DM. Platelet-rich fibrin [PRF]: A secondgeneration platelet concentrate. Part IV: Clinical effects on tissue healing. Oral Surg Oral Med Oral Pathol Oral Radiol Endod. 2006; 101(3): e56-e60.

[20] Aroca S, Keglevich T, Barbieri B, Gera I, Etienne D. Clinical evaluation of a modified coronally advanced flap alone or in combination with a platelet rich fibrin membrane for the treatment of adjacent multiple gingival recessions: a 6-month study. Journal of Periodontology. 2009; 80(2):244-252.

[21] Simonpieri A, Del Corso M, Sammartino G, Ehrenfest DMD. The relevance of Choukroun's platelet-rich fibrin and metronidazole during complex maxillary rehabilitations using bone allograft. Part I: a new grafting protocol. Implant Dent. 2009; 18(2):102-111.

[22] Hartshorne J, Gluckman H. A comprehensive clinical review of Platelet Rich Fibrin [PRF] and its role in promoting tissue healing and regeneration in dentistry. Part II: Preparation, optimization, handling and application, benefits and limitations of PRF. international dentistry - African edition. 2016; 6(5): 34-48.

[23] Schultze-Mosgau S, Schmelzeisen R, Frolich JC, Schmele H. Use of ibuprofen and methylprednisolone for the prevention of pain and swelling after removal of impacted third molars. Journal of Oral and Maxillofacial Surgery. 1995; 53(1):2-7.

[24] Neupert III EA, Lee JW, Philput CB, Gordon JR. Evaluation of dexamethasone for reduction of postsurgical sequelae of third molar removal. J Oral Maxillofac Surg. 1992; 50(11): 1177-1182.

[25] McCaffrey M, Beebe A. Giving narcotics for pain. Nursing. 1989; 19(10):161-5.

[26] Grossi GB, Maiorana C, Garramone RA, Borgonovo A, Creminelli L, Santoro F. Assesing postoperative discomfort after third molar surgery:A prospective study. J Oral Maxillofacial Surg. 2007; 65(5):90117.

[27] Nyman E, Henricson J, Ghafouri B, Anderson CD, Kratz G. Hyaluronic acid accelerates reepithelialization and alters protein expression in a human wound model. Plastic and Reconstructive Surgery Global Open. 2019; 7(5): e2221.

[28] Singh A, Kohli M, Gupta N. Platelet rich fibrin: a novel approach for osseous regeneration. Journal of maxillofacial and oral surgery. 2012; 11(4):430434.

[29] Kumar N, Prasad K, Ramanujam L, K R, Dexith J, Chauhan A. Evaluation of Treatment Outcome after Impacted Mandibular Third Molar Surgery with the Use of Autologous Platelet-Rich Fibrin: A Randomized Controlled Clinical Study. J Oral Maxillofac Surg. 2015; 73(6): 1042-1049.

[30] Das A, Neher JO, Safranek S. Do hyaluronic acid injections relieve OA knee pain? Clinical inquiries 2009 (MU).

[31] Hammed A, and Deleme ZH. The effects of bioadhesive hyaluronic acid gel versus diclofenac 
after surgical removal of impacted wisdom teeth. Journal of Oral Research. 2019; 1(1):28-31.

[32] Al-Hamed FS, Tawfik MAM, Abdelfadil E. Clinical effects of platelet-rich fibrin [PRF] following surgical extraction of lower third molar. The Saudi Journal for Dental Research. 2017; 8(1-2): 19-25.

[33] Yilmaz N, Demirtas N, Kazancioglu H, Bayer S, Acar A, Mihmanli A. The efficacy of hyaluronic acid in postextraction sockets of impacted third molars: A pilot study. Nigerian journal of clinical practice. 2017: 20(12): 1626-1631.

[34] Peterson L J. Postoperative patient management. In: Peterson LJ, Ellis E, Hupp JR, Tucker MR, editors. Contemporary oral and maxillofacial surgery. 4th ed. St. Louis: CV Mosby; 2003; P.214-20.

[35] Koray M, Ofluoglu D, Onal E, et al. Efficacy of hyaluronic acid spray on swelling, pain, and trismus after surgical extraction of impacted mandibular third molars. International journal of oral and maxillofacial surgery.2014: 43(11): 1399-1403.

[36] Nelson FR, Zvirbulis RA, Zonca B, et al. The effects of an oral preparation containing hyaluronic acid [Oralvisc $®]$ on obese knee osteoarthritis patients determined by pain, function, bradykinin, leptin, inflammatory cytokines, and heavy water analyses. Rheumatology international. 2015: 35(1): 43-52.

[37] Cooper CA, Brown KK., Meletis CD, \& Zabriskie N. [2008]. Inflammation and hyaluronic acid. Alternative \& complementary therapies, 14(2), 7884.

[38] Ozgul O, Senses F, Er N, Tekin U, Tuz HH, Alkan A, Koçyiğit ID, Atıl F. Efficacy of platelet rich fibrin in the reduction of the pain and swelling after impacted third molar surgery: Randomized multicenter split-mouth clinical trial. Head and Face medicine. 2015; 11(1):1-5.

[39] Gocmen G, Aktop S, Tüzüner B, Goker B, Yarat A. Effects of hyaluronic acid on bleeding following third molar extraction. Journal of Applied Oral science. 2017: 25(2): 211-216.

[40] Afat IM, Akdoğan ET, \& Gönül O. Effects of leukocyte-and platelet-rich fibrin alone and combined with hyaluronic acid on early soft tissue healing after surgical extraction of impacted mandibular third molars: a prospective clinical study. Journal of Cranio-Maxillofacial Surgery. 2019; 47(2]: 280-286.
[41] Bilginaylar K, Uyanik LO. Evaluation of the effects of platelet-rich fibrin and piezosurgery on outcomes after removal of impacted mandibular third molars. British Journal of Oral and Maxillofacial Surgery. 2016; 54(6):629-633. 